\title{
Sciendo
}

DOI 10.2478/afepuc-2021-0011

(C) 2021 Author(s). This is an open access article licensed under the Creative Commons Attribution-NonCommercial-NoDerivatives 4.0 International

(https://creativecommons.org/licenses/by-nc-nd/4.0/)

\section{RETURN TO EXERCISE AFTER COVID-19: WHICH ONE IS THE BEST STRATEGY?}

\author{
Murat Erdoğan ${ }^{1}$, Sevgi Sökülmez-Yildirim² ${ }^{2}$ Nasuh Evrim Acar ${ }^{3}$, Okan Kamiş ${ }^{4 *}$ \\ ${ }^{I}$ Department of Physical Fitness Tests Unit, Turkish Armed Forces Sports School, Ankara, Turkey; \\ ${ }^{2}$ Infectious Diseases and Clinical Microbiology, Gülhane Training and Research Hospital, Ankara, Turkey; \\ ${ }^{3}$ Faculty of Sport Sciences, Mersin University, Mersin, Turkey; \\ ${ }^{4}$ Department of Sports and Health, Aksaray University, Aksaray, Turkey
}

\begin{abstract}
Summary: Coronavirus (Covid-19), which began in China as of 2019 and spread to almost all over the world in a short time; has shown that we need to plan our life with new strategies as well as changing our current lifestyle today. While we must implement new ways to prevent against Covid-19 and maintaining our healthy lives, we must also design new strategies for returning to sports and physical activities. Therefore, the purpose of this study was to reveal the return strategies for professional and recreational athletes during the quarantine periods in light of evidences. In this regard, firstly we examined the existing literature regarding return strategies to sports. As a result, individual performance and personal hygiene conditions should be considered, and athletic performance should be preserved while keeping a physical distance from teammates and others. The use of masks in sports should be encouraged, but new techniques should be developed by investigating the effect on performance. Consequently, for healthy individuals, low to moderate intensity (not high-intensity) exercise may be beneficial and recommend. However, due to the risk of spreading (person-to-person or contaminated surfaces), exercise is recommended in special places with good ventilation and the use of personal types of equipment.
\end{abstract}

Key Words: Covid19, Coronavirus, Exercise, Sports, Performance

\section{Introduction}

COVID-19, which was caused by a coronavirus that originated regionally in China but quickly expanded over the world, was declared a pandemic by the World Health Organization on March 11, 2020 (World Health Organization 2020). Covid-19 is caused by a virus from the corona viridae family, which belongs to the same subfamily as SARS-CoV-2, which first 
appeared in China in November 2002. SARS-CoV-2 is a positive-polarity enveloped RNA virus. The virus's sickness was initially recognized as non-fatal pneumonia, but by the time the study was completed (on July 20, 2020), the disease had been detected in 14.507.491 instances worldwide and had already killed 606.173 people (Wikipedia 2020).

Common symptoms of COVID-19 disease are fever (88\%), continuous dry cough (68\%), fatigue (38\%), phlegm (33\%), difficulty breathing (19\%), sore throat (14\%), headache (14\%) and muscle and joint pains (15\%) (Buruk and Özlü 2020). The disease's progression evolved with time, and it became fatal especially in the elderly and those with chronic illnesses (heart diseases, diabetes, hypertension, respiratory disorders, cancer, etc.) (American College of Sports Medicine 2020; Graziano, Giovanni \& Silvio 2020).

Covid-19 is commonly spread through respiratory droplets. Furthermore, non-sick people come into contact with contaminated respiratory droplets on objects left by sick persons coughing, sneezing, or touching, and these non-sick people develop mycosis of the mouth, nose, or eyes. This intense transmission method has a detrimental impact on life and makes physical exercise a tough way of life (American College of Sports Medicine 2020). Personal isolation is the best technique of disease prevention, but exercising is required to make this lifestyle more meaningful and to maintain a certain level of physical activity (PA) and a satisfactory level of health (Lavie et.al. 2019; Fletcher et. al. 2018). In light of scientific findings, this review investigated into the return strategies of both professional and recreational athletes to exercise during and after the quarantine period.

\section{Methods}

\section{Exercises and immune system interaction}

All living organisms are born with a defense system that protects them against external tissues, cells, and chemicals. In humans, this system, known as the immune system, responds to exercise in a variety of ways. The severity and duration of the immune system's reactions to exercises are linked to a person's health. Exercises also have both acute and long-term effects on the human body and mind. According to several studies, exercising on a regular basis has a good impact on people's immune systems (Barrett et. al. 2012; Niemann and Wentz 2019) while some other studies report that a single bout of exercise (acute exercise) can also produce positive effects upon the immune system (Dimitrov, Hulteng \& Hong 2018). During and immediately after exercise, the number of total white blood cells (leukocytes) in circulation generally 
increases. These leukocytes are related to the intensity and duration of activity, and peak near the end of short-term, high-intensity workouts (McCarthy and Dale 1998).

The increase in the number of leucocytes may be higher during exercises done in hot settings. In the post-exercise period, the number of lymphocytes and monocytes in circulation is observed to characteristically be lower than the number of lymphocytes and monocytes in rest (Gabriel et.al. 1992; Moyna et.al. 1996; Nieman, Nehlsen-Cannarella \& Donohue 1991). This causes an increase in the number of neutrophils in circulation to continue for a while after exercise (Fry et. al. 1992).

After acute exercises, the effect of natural killer (NK) cells -a kind of lymphocytes measured in this manner- upon cell function is quite steady. An increase in NK cell function due to intensity is commonly reported during or just after exercises. As a result of running with moderate intensity for 45 minutes (50 \% VO2max) (Nieman et.al. 1993a); NK cell function may go up by $50 \%$ whereas NK cell function may be elevated by $100 \%$ in exercises like running and cycling done with high intensity (70 - $80 \%$ VO2max) (Pedersen, Tvede, \&Klarlund 1990; Shek et. al. 1995).

Within one hour -at the latest- after exercises, NK cells decrease below the level of the pre-exercise period. If the length of high-intensity exercises is longer, NK cells main defense system of the body are suppressed (Tvede 1989); which makes the body vulnerable to infections in the post-exercise period. This period in which the immune system weakens is known as the "open window" theory that enables infections to enter organisms (Nieman et.al. 1993a; Nieman 1994).

American College of Sports Medicine (ACSM) reports that physically active groups contract infectious diseases more as compared to sedentary groups (Keast et.al. 1995; Nieman et al. 1993b; Nieman et al. 2006), assessed upper respiratory disorders in 155 marathon runners who run $160 \mathrm{~km}$ and $24 \%$ of the athletes suffered from upper respiratory disorders. Peters \& Bateman (1983) found that the incidence of upper respiratory disorders in 141 south African marathon runners was twofold higher than the control group after a race of $56 \mathrm{~km}(33.3 \% \mathrm{vs}$. $15.3 \%)$.

Australian Exercise and Sports Science Association advises about the fact that the immune system is supported with exercises and encourages not only the young but also the elderly to do exercises and to move more. According to a study conducted at Birmingham University and King's College London in 2018, it was identified that 125 amateur cyclists who did not smoke and were aged between 55 and 79 still had immune systems similar to the young. Australian Exercise and Sports Science Association CEO Anita Hobson-Powell made a 
statement about the potential effects of COVID-19 and indicated that studies are emphasizing that exercises can support our immune system and exercises should be done because they support our mental health (Exercise and Sports Science Australia 2020).

Immune system response in exercises is directly correlated with severity and length of training. High-intensity exercises elevate upper respiratory infection risks whereas moderateintensity exercises reduce upper respiratory infection risk (Şenışık 2015).

\section{Return strategies to exercise}

Maintaining or returning to physical activity during or after infectious disorders is one of the issues exercise physiologists often asked. If the symptoms of an upper respiratory infection are restricted to coughing, sneezing, and a sore throat, the person should jog for 10 minutes. If a person's general health and symptoms worsen, they are advised to refrain from physical activity until they have fully recovered. If an individual's condition does not change after a 10-minute run, he or she is allowed to engage in low to moderate physical activities with a VO2max of less than $80 \%$. If the symptoms are severe, such as myalgia, fever, or gastrointestinal complaints, physical activity should be discouraged until the patient is fully recovered (Eichner 1993; Harris 2011).

The current treatment appears to be to stop exercising until the athlete heals. At this time, the most serious risk of contracting COVID-19 is being exposed to the virus. We need to come up with new strategies to exercise while maintaining physical distance and maintaining proper hygiene. For example, we can keep a certain distance from friends while running, shoot and pass the ball from a distance in football, or keep a social distance while cycling. Even if exercise does not prevent us from becoming infected, staying active can reduce the harmful effects of viruses, heal symptoms, shorten recovery times, and strengthen our immune system, reducing the possibility of infection.

\section{Recreational athletes}

If social distance is maintained, moderate-intensity aerobic exercises (such as brisk walking) can be appropriate alternatives for those who participate in outdoor sports for health reasons. However, high-intensity exercises performed in public indoor facilities and crowded areas can cause more harm than good. Even if necessary hygiene precautions are taken, the presence of an excessive number of athletes in these locations at the same time should be avoided in order to maintain social distance. 
An exercise program consisting of easy workouts at home might also be recommended as an option to prevent the coronavirus in the air and maintain fitness levels. This program can include aerobics (at-home walking), resistance exercise, stretching, flexibility, and balance exercises, or a mix of this type of exercises (Chen et.al. 2020). However, when conducted at a moderate intensity during the quarantine period, these activities are said to be suitable (40 $60 \%$ heart rate reserve or $65-75 \%$ of max heart rate) (Jiménez-Pavón et.al. 2020).

Exercises that will terminate a lack of physical activity should start with low-intensity activities. Especially, first training should consist of exercises done in a short distance and in a short time. Individuals should avoid high-intensity activities during the early stages of training. The heartbeat can be used to determine the intensity of a workout for persons who are exercising. If your heart rate is too high, you should lessen the intensity of your workout. Furthermore, taking a day off can be useful in some situations (Erdoğan 2019). Moreover, people should pay attention to feedbacks to be delivered by their bodies and give enough rest pauses between exercises. A sufficient level of sleep is critically important. Each day after each exercise unit, a sufficient level of rest is essential and positive thinking should be a principle (Wingenfeld 2020).

In this subject, ACSM recommends that as long as one stays in the open air and keeps a social distance of 2 meters (with the assent of the authorities); walking or running activities, being physically active in parks, cycling, and gardening such as grassing should be done. Besides; people should abstain from sitting in front of the TV at home and instead; they should perform physical activities by downloading exercise applications to smartphones such as doing yoga, squatting or sitting exercises with a strong chair, lunge exercises with stairs or push up exercises against a wall (American College of Sports Medicine 2020).

\section{Performance athletes}

In addition to those doing sports for health, the situation of this group doing sports professionally is more serious because professional athletes do as much as they can to preserve physical performance. Professional athletes may believe that their performances have decreased during the sickness days, but with coaches pressuring them to return to training as quickly as possible, players return to exercises and training before fully recovering. It is the athletes' obligation to understand that the virus has entirely lost its efficacy and to feel well.

Athletes should be conscious of their current recovery status, and while coaches may encourage them, they should not be rushed. If athletes still experience a fever and cough from occasionally, they cannot be considered to be free of Covid-19 symptoms. Once these 
symptoms occur, you will be unable to continue training and activities. In order to return to sports, athletes must have confidence in themselves. They should postpone off training and exercise for a while if they are unsure about themselves. At this level, a negative Covid-19 test is necessary. You must be assured that your disease has completely passed. It takes longer for an athlete to return to his prior level of performance the longer he is sick.

Getting a satisfactory rest and sleep between training is crucial. Each day after training, the rest should be taken. Athlete's age, gender and training experience plays a key role in returning to trainings (Wingenfeld 2020). Blocken et al. (2020), argued that to protect the athletes coming behind, the distance should be 4-5 meters for walking, 10 meters for running and 20 meters for cycling since the virus hangs in the air.

Since physical contact is inevitable in sportive branches, infection risk is higher and therefore it is plausible to delay or cancel sportive tournaments and competitions. Yet, when it is impossible to delay or to cancel sportive tournaments for good reasons, matches should be organized without spectators by following protective and hygienic measures in maximum. Therefore; accepted as the world's biggest sports organization, the Tokyo 2020 Olympic and Paralympic Games that will be held in summer 2020 with the participation of 15000 athletes and 20 million visitors from all over the world have been postponed until 2021 (Gallego et.al. 2020). Professional athletes need to perform high-intensity exercises to maintain their performances. Considering that high-intensity exercises suppress the immune system, professional athletes are advised to go on high-intensity exercises on the condition that they strictly follow isolation regulations (by cutting contacts with others completely) (Aktug et.al. 2020).

\section{Infected athletes}

There are two different groups in guiding and counselling quarantined and infected athletes' or recreative athletes' activities. The first group is those athletes who have a positive test result with no symptoms whereas the second group is those athletes who have a positive test result and demonstrate positive symptoms. The latter group of athletes should directly receive medical assistance, discontinue exercises and act according to physicians' recommendations. Those in the first group with, no symptoms despite positive test result, can go on moderate-intensity activities but firmly follow quarantine regulations so that virus does not infect other athletes or people. If they later on the present with fever, coughing or short of breath; physical activity should be quitted and a medical care provider or a physician should be contacted (American College of Sports Medicine 2020). 


\section{Discussion and conclusion}

The main purpose of this brief review was to to reveal the return strategies for both professional and recreational athletes during the quarantine periods in light of evidences. Diseases with high infection rate such as Covid-19 affect all athletes. In particular, necessary measures should be taken to prevent disease spread during organizations like sportive tournaments, competitions and training in which athletes come together. It should be kept in mind that elite athletes are in high-risk groups. Since elite athletes as a part of their lifestyles are popular and get in touch with many people; they should be more careful about personal hygiene. In this respect, disease prevention becomes more important for elite athletes (Mark \& Harris 2014). Nowadays, with the Covid-19 pandemic, physical performance should be kept under control at an individual level by following protective measures and keeping social/ physical distance from teammates and other people. Masks should also be a part of sports activities for some time as in every activity. Those athletes testing positive but showing no symptoms should stay away from doing high-intensity exercises and go on low to moderate intensity exercises by taking necessary measures. When symptoms develop, training should be quitted, and medical control should be sought.

After inactivity periods, athletes susceptible to physical injuries (Caterisano et.al. 2019; NCAA's Interassociation Recommendations 2019). Due to the safety-in-place restrictions during the COVID-19, nearly all training by athletes has been limited or interrupted. For this reason, there are some outcomes for coaches and athletes after returning to training. One of the most important outcomes are that increased risks of injury and overtraining as well as adverse weight gain, weight loss and changes to body composition (National Strength and Conditioning Association 2020).

In those athletes who were infected but recovered, it should be confirmed by a medical physician that they have recovered from the disease before they return to exercises and training. After the result of physical examination done by a physician is acceptable; each athlete should receive a detailed test protocol and this test protocol should include aerobic tests, strength and speed tests, neuro-muscular tests, and flexibility tests. In conclusion, low- to moderate-intensity exercise can be beneficial to healthy persons and is thus suggested. However, due to the significant danger of contamination, it is recommended that workouts be performed in private settings (for example, at home) with good air conditioning and personal equipment (from a person or contaminated places to person). If an athlete shows Covid19 symptoms, they should 
follow national guidelines, consult a sports medicine doctor, abide to quarantine restrictions, and follow testing and tracking protocols (Elliot et.al. 2020).

\section{Conflict of Interest}

The authors declare no conflict of interest and do not have any financial disclosures.

\section{Limitations}

The case and death numbers that mentioned in this study can be change during the Covid-19 as of publishing date.

\section{References}

1. AKTUĞ, Z.B., R. İRİ \& N. A. DEMIR, 2020. COVID-19 Immune System and Exercise. International Journal of Human Sciences. 17(2), pp.513-520. https://doi.org/10.14687/jhs.v17i2.6005

2. AMERICAN COLLEGE OF SPORTS MEDICINE, 2020. Staying Physically Active During the Coronavirus Pandemic. [document on the internet]; Available from: https://www.acsm.org/read-research/newsroom/news-releases/news-

detail/2020/03/16/staying-physically-active-during-covid-19-pandemic, https://doi.org/10.1016/j.bbi.2020.04.041

3. BARRETT, B., M. S. HAYNEY, D. MULLER, D. RAKEL, A. WARD \& C. N. OBASI, 2012. Meditation or exercise for preventing acute respiratory infection: a randomized controlled trial. Ann Fam Med. 10:337-346, https://doi.org/10.1186/1472-6882-12-s1-p92

4. BLOCKEN, B., F. MALIZIA, T. VAN DRUENEN \& T. MARCHAL, 2020. Social Distancing v2.0: During Walking, Running and Cycling.[document on the internet]. Available

from:https://media.real.gr/filesystem/Multimedia/pdf/Social_Distancing_v20_White_Pape $\underline{\text { r_id38170.pdf }}$

5. BURUK, K. \& T. ÖZLÜ, 2020. New Coronavirus SARS-COV-2. Mukosa. 3 (1), 1-4.

6. CATERISANO, A., D. DECKER, B. SNYDER, M. FEIGENBAUM, R. GLASS, P. HOUSE, C. SHARP, M. WALLER \& Z. WITHERSPOON, 2019. CSCCa and NSCA Joint Consensus Guidelines for Transition Periods. Strength and Conditioning Journal. 41(3), 123. 
7. CHEN, P., L. MAO, G. P. NASSIS, P. HARMER, BE. AINSWORTH \& F. LI, 2020. Wuhan coronavirus (2019-nCoV): The need to maintain regular physical activity while taking precautions. J Sport Health Sci. 9 (2):103-4.

https://doi.org/10.1016/j.jshs.2020.02.001

8. DIMITROV, S., E. HULTENG \& S. HONG, 2017. Inflammation and exercise: inhibition of monocytic intracellular TNF production by acute exercise via $\beta 2$-adrenergic activation. Brain Behav Immun. 61:60-68, https://doi.org/10.1016/j.bbi.2016.12.017

9. EICHNER, E. R., 1993. Infection, Immunity, and Exercise. Phys Sportsmed. 21(1):125-35.

10. ELLIOTT, N., R. MARTIN, N. HERON, J. ELLIOTT, D. GRIMSTEAD \& A. BISWAS, 2020. Infographic. Graduated return to play guidance following COVID-19 infection. British Journal of Sports Medicine. 54(19), 1174-1175.

11. ERDOĞAN, M., 2019. 40 Yaş Üzeri Egzersiz Rehberi. Nobel Bookstore.

12. EXERCISE AND SPORTS SCIENCE AUSTRALIA (ESSA), 2020. COVID- 19 Response: Why exercise is more important than ever. Available from: https://www.essa.org.au/Public/News_Room/Media_Releases1/2020/COVID19_Respons e_Why_exercise_is_more_important_than_ever.aspx, https://doi.org/10.7748/ns.35.4.40.s19

13. FLETCHER G. F., C. LANDOLFO, J. NIEBAUER, C. OZEMEK, R. ARENA \& C. J. LAVIE, 2018. Promoting physical activity and exercise: JACC health promotion series. $J$ am Coll Cardiol. 72(14):1622-1639, https://doi.org/10.1016/j.jacc.2018.08.2141

14. FRY, R., A. MORTON, G. CRAWFORD \& D. KEAST, 1992. Cell numbers and in vitro responses of leukocytes and lymphocyte subpopulations following maximal exercise and interval training sessions of different intensities. Eur. J. Appl. Physiol. Occup. Physiol. 64:218-227, https://doi.org/10.1007/bf00626284

15. GABRIEL, H., L. SCHWARZ, P. BORN \& W. KINDERMANN, 1992. Differential mobilization of leukocyte and lymphocyte subpopulations into the circulation during endurance exercise. Eur. J. Appl. Physiol. Occup. Physiol. 65:529-534.

16. GALLEGO, V., H. NISHIURA, R. SAH, \& A. J. RODRIGUEZ-MORALES, 2020. The COVID-19 outbreak and implications for the Tokyo 2020 Summer Olympic Games. Travel Med Infect Dis. 101604, https://doi.org/10.1016/j.tmaid.2020.101604

17. GRAZIANO, O., R. GIOVANNI \& B. SILVIO, 2020. Case-Fatality Rate and Characteristics of Patients Dying in Relation to COVID-19 in Italy. JAMA. 323 (18), 17756, https://doi.org/10.1001/jama.2020.4683

18. HARRIS, M. D., 2011. Infectious disease in athletes. Curr Sports Med Rep. 10(2):84-9. 
19. JIMÉNEZ-PAVÓN, D., A. CARBONELL-BAEZA \& C. J. LAVIE, 2020. Physical exercise as therapy to fight against the mental and physical consequences of COVID-19 quarantine: Special focus in older people. Prog Cardiovasc Dis. [Epub ahead of print], https://doi.org/10.1016/j.pcad.2020.03.009

20. KEAST, D., D. ARSTEIN, W. HARPER, R. FRY \& A. MORTON, 1995. Depression of plasma glutamine concentration after exercise stress and its possible influence on the immune system. Med. J. Aust. 162:15-18, https://doi.org/10.5694/j.1326$\underline{\text { 5377.1995.tb138403.x }}$

21. LAVIE, C. J., C. OZEMEK, S. CARBONE, P. T. KATZMARZYK \& S. N. BLAIR, 2019. Sedentary behavior, exercise, and cardiovascular health. Circ Res. 124(5):799-815, https://doi.org/10.1161/circresaha.118.312669

22. MARK, D. \& M. D. HARRIS, 2011. Infectious Disease in Athletes Current Sports Medicine Reports. The American College of Sports Medicine. 10(2). https://doi.org/10.1249/jsr.0b013e3182142381

23. MCCARTHY, D. \& M. DALE, 1988. The leucocytosis of exercise. Sports Med. 6:333363.

24. MOYNA, N. M., G. R. ACKER, K. M. WEBER, J. R. FULTON, F. L. GOSS, R. J. ROBERTSON \& B. S. RABIN, 1996. The effects of incremental submaximal exercise on circulating leukocytes in physically active and sedentary males and females. Eur. J. Appl. Physiol. Occup. Physiol. 74:211-218, https://doi.org/10.1007/bf00377443

25. NATIONAL STRENGTH AND CONDITIONING ASSOCIATION, 2020 COVID-19 Return to Training Task Force. COVID-19, [document on the internet]; NSCA Guidance on Safe Return to Training for Athletes.

26. NCAA'S INTERASSOCIATION RECOMMENDATIONS, 2019. Preventing Catastrophic Injury and Death in Collegiate Athletics; Accessed April 13, 2020. Available at:

https://ncaaorg.s3.amazonaws.com/ssi/injury_prev/SSI_PreventingCatastrophicInjuryBoo klet.pdf

27. NIEMAN, D. C., S. L. NEHLSEN-CANNARELLA \& K, M. DONOHUE, 1991. The effects of acute moderate exercise on leukocyte and lymphocyte subpopulations. Med. Sci. Sports Exerc. 23:578-585, https://doi.org/10.1249/00005768-199105000-00010

28. NIEMAN, D. C., A. R. MILLER, D. A. HENSON, B. J. WARREN, G. GUSEWITCH \& R. L. JOHNSON, 1993a. Effects of high- versus moderate- intensity exercise on natural 
killer cell activity. Med Sci Sports Exerc. 25:1126-34, https://doi.org/10.1249/00005768$\underline{199310000-00008}$

29. NIEMAN, D. C., D. A. HENSON, G. GUSEWITCH, B. J. WARREN, R. C. DOTSON, D. E. BUTTERWORTH \& S. L. NEHLSEN-CANNERELLA, 1993b. Physical activity and immune function in elderly women. Med. Sci. Sports Exerc. 25:823-831.

30. NIEMAN, D. C., 1994. Exercise, infection, and immunity. Int J Sports Med. 15(3):131-41.

31. NIEMAN, D. C., D. A. HENSON, C. L. DUMKE \& R. H. LIND, 2006. Relationship between salivary IgA secretion and upper respiratory tract infection following a $160-\mathrm{km}$ race. Journal of Sports Medicine and Physical Fitness. 46 (1), 158-62.

32. NIEMAN, D. C. \& L. M. WENTZ, 2019. The compelling link between physical activity and the body's defense system. J Sport Health Sci. 8:201-217, https://doi.org/10.1016/j.jshs.2018.09.009

33. PEDERSEN, B.K., N. TVEDE \& K. KLARLUND, 1990. Indomethacin in vitro and in vivo abolishes post-exercise suppression of natural killer cell activity in peripheral blood. Int. $J$. Sports Med. 11:127-131, https://doi.org/10.1055/s-2007-1024776

34. PETERS, M. \& E. D. BATEMAN, 1983. Ultramarathon running and upper respiratory tract infections an epidemiological survey. SA Medical Journal.64 (1).

35. ŞENIŞIK, S. Ç., 2015. Exercise and immune system. Turk J Sports Med. 50, 11-20.

36. SHEK, P. N., B. H. SABISTON, A. BUGUET \& M. W. RADOMSKI, 1995. Strenuous exercise and immunological changes: a multiple-time-point analysis of leukocyte subsets, CD4/CD8 ratio, immunoglobulin production and NK cell response. Int. J. Sports Med. 16:466-474, https://doi.org/10.1055/s-2007-973039

37. TVEDE, N., C. HEILMANN, J. HALKJAER-KRISTENSEN \& B. K. PEDERSEN, 1989. Mechanisms of B-lymphocyte suppression induced by acute physical exercise. J Clin Lab Immunol. 30:169-73.

38. WIKIPEDIA, 2020. COVID-19. Available from https://en.wikipedia.org/wiki/COVID 19_pandemic

39. WINGENFELD, S., 2020. Running after a cold? This Training plan will help you get back to running. Available from: https://www.runtastic.com/blog/en/running-after-a-cold/ 12.02.2020.

40. WORLD HEALTH ORGANISATION, 2020. Coronavirus disease (COVID-19)[document on the internet]. Available from: https://www.who.int/health-topics/coronavirus\#tab=tab 